\title{
The use of emergency contraception among female senior high students in the Ho municipality of the Volta Region, Ghana
}

\author{
Kennedy D. Konlan ${ }^{1}$, Roberta M. Amoah ${ }^{2 *}$, Joel A. Saah², Abdul Razak Doat ${ }^{3}$, \\ Kennedy Dodam Konlan ${ }^{4}$, Milipaak Japiong ${ }^{5}$, Juliana A. Abdulai ${ }^{6}$
}

\begin{abstract}
${ }^{1}$ Department of Public Health Nursing, School of Nursing and Midwifery, University of Health and Allied Sciences, Ho, Volta Region, Ghana

${ }^{2}$ Department of Public Health, School of Allied Sciences, University for Development Studies, Tamale Northern Region, Ghana

${ }^{3}$ Tehran University of Medical Science- School of Nursing and Midwifery, Tehran, Iran

${ }^{4}$ Department of Adult Health, School of Nursing and Midwifery, University of Ghana, Legon, Greater Accra Region, Ghana

${ }^{5}$ Department of Nursing, University of Health and Allied Sciences, School of Nursing and Midwifery, Ho, Ghana

${ }^{6}$ Department of Surgery, Tamale Teaching Hospital, Tamale, Northern Region, Ghana
\end{abstract}

Received: 10 April 2020

Accepted: 02 May 2020

\section{*Correspondence:}

Dr. Roberta M. Amoah,

E-mail: mensima3199efua@gmail.com

Copyright: (c) the author(s), publisher and licensee Medip Academy. This is an open-access article distributed under the terms of the Creative Commons Attribution Non-Commercial License, which permits unrestricted non-commercial use, distribution, and reproduction in any medium, provided the original work is properly cited.

\section{ABSTRACT}

Background: Emergency contraception (EC) is one option for preventing unplanned pregnancy when it is available and properly used. Unsafe abortions are responsible for nearly one third of maternal deaths in sub-Saharan Africa and about quarter of unsafe abortions are among teenagers.

Methods: A quantitative descriptive cross-sectional study. Data was collected using a pretested questionnaire. 260 senior high students were selected using a systematic sampling method in the Volta Region, Ghana. Data were cleaned and entered into SPSS version 22 and analysed into descriptive statistics.

Results: Respondents acquired awareness about EC from friends (36.9\%), family members $(5.6 \%)$ and the mass media (41.6\%). The required time for EC to be taken were stated as immediately after sex (57.9\%), 24 hours after sex $(1.2 \%)$ and $(30.6 \%)$ did not know. $28.4 \%$ of participants indicated they would not use EC in the future as their faith was against it, $18.0 \%$ believed EC is ineffective and $24.9 \%$ consider it dangerous to their health. Reasons for use of EC included condom slipped (35.7\%), inability to be on daily pill $(33.7 \%)$, forced unprotected sex $(8.2 \%)$ and miscalculation of the safe menstrual period $(22.4 \%)$. There was a significant relationship between age and history of use of $E C$ ( $p=0.000, c 2=8.128, n=260)$.

Conclusions: Strengthening education in Senior High Schools on sexual and reproductive health, with special emphasis on emergency contraceptives as a pregnancy preventive procedure will remain imperative to reducing the canker of maternal mortality attributed to adolescent abortions while improving understanding of the appropriate use of EC.

Keywords: Abortions, Emergency contraception, Pregnancy, Pills, Sex, Teenagers

\section{INTRODUCTION}

According to the World Health Organization (WHO) fact sheet 2016, "Emergency contraception (EC) is a type of birth control device used to prevent unwanted pregnancies resulting from unintended sexual activities, contraceptive failure, rape or coerced unprotected sex". Emergency contraception pills and Copper- bearing 
intrauterine devices are the main methods. ${ }^{1}$ Three types of EC pills are available; combined oestrogen and progestin pills, progestin only pills, and oestrogen pills. ${ }^{1}$ EC was thought to be effective only within 72 hours, but recent studies have confirmed it is effective for up to 120 hours. The intrauterine device (IUD) can be used safely for emergency contraception up to 5-7 days after unprotected intercourse. ${ }^{2}$ The mechanisms of action of emergency contraceptives are: by inhibiting ovulation or preventing the implantation of the fertilized egg, however, will not terminate or interfere with a pregnancy once it's established. The rate of unintended pregnancy is higher in developing countries (57 per 1000 women between the ages of 15-44) as compared to the developed countries (42 per 1000 women between the ages of 15 44). ${ }^{3}$

EC is one option for preventing unplanned pregnancy when it is available and properly used. ${ }^{4}$ Noteworthy, about 46 million pregnancies $(22 \%$ of the total pregnancies and $61 \%$ of the unplanned/unintended pregnancies) are aborted. ${ }^{5}$ In Africa, about one-quarter of unsafe abortions are among teenagers (aged 15 to 19), a higher proportion than in any other region of the world. ${ }^{7}$ In Ghana, $14 \%$ of women within the ages 15-19 start bearing children; and $39 \%$ of registered pregnant cases being between 10-24 years with $2.3 \%$ of reported pregnant cases result in abortions. ${ }^{8}$

In many low and middle-income countries, like Ghana, students resort to unsafe abortion due to lack of knowledge, access and utilization of EC4. ECs are the only methods that can be used within a short period of time to prevent unwanted pregnancy if used correctly and timely since most of the regular methods are used before or during sexual intercourse. ${ }^{9}$ In spite of this, some studies have revealed the limited knowledge of emergency contraception among female students. ${ }^{6}$

In Ghana, the median age at first intercourse among women is 18.4 years, more than two years lower than the median age at first marriage; 20.7 years. ${ }^{8}$ This makes more-young females in Ghana prone to teenage pregnancy and its intended consequences. ${ }^{10}$

In $2014,23.2 \%$ and $11.2 \%$ of teenage pregnancies were recorded in Adaklu district and Ho municipality respectively predisposing these areas to problems like high perinatal deaths and low birth weight. ${ }^{8,11}$ Preventing adolescent pregnancy is a key strategy in improving maternal and infant outcomes yet little is known about this effective strategy (EC utilization) in the Ho municipality. Few studies have been conducted to assess senior high students' awareness and use of emergency contraception.

This study assessed the utilization of emergency contraceptive among female senior high students in the Ho municipality of Ghana.

\section{METHODS}

\section{Study design}

This was a descriptive cross-sectional study. Data was collected from respondents at a point in time and no follow up was required.

\section{Study setting and population}

Ho is the administrative capital of the Volta Region and plays host to many senior high schools. Senior high schools in the metropolis are of mixed and single sex institutions ranging from government, private, religious based, to community owned. All these institutions were listed and three were selected for the study based on simple random sampling. Sonrise Christian senior high school is a mixed school with a total population of 400 students. The Star senior high school is also a mixed school with a total population of 66 students with 42 being females and 24 males. The Sacred Heart Senior High School another a mixed school with a total population of 153 students with 89 of the students being females and 64 males.

\section{Sample and sampling technique}

A systematic sampling method was used to select 260 girls from the selected three senior high schools in the municipality.

In determining the sample size, Kish and Leslie formula was used. The formula is.

$\mathrm{n}=\frac{z^{2} \times(P) \times(1-P)}{d^{2}}=\frac{(1.645)^{2} \times(0.6) \times(0.4)}{(0.5)^{2}}$

$\mathrm{n}=259.78 .16 \approx 260$

Where: $n=$ desired sample size $\mathrm{Z}=$ value for $90 \%$ confidence level and the value is expressed as 1.69 $\mathrm{p}=$ percentage picking as a choice $(0.6) . \mathrm{d}=$ confidence interval, expressed as (0.05).

In each institution a sample fraction was calculated, girls sitting in their respective classes were selected based on the calculated sample fraction. Based on proportional allocation of $3: 2: 1,160$ female students were selected from Sonrise Christian senior high school, 70 female students from Sacred Heart senior high school and 30 female students from Star senior high school.

\section{Data collection and analysis}

A pretested questionnaire was used for data collection. The questionnaire was modified until it produced a Cronbach alpha coefficient of 0.791 . Section "A" covered demographic and biographical information, "B" assessed knowledge of EC, section " $\mathrm{C}$ " contained items regarding attitudes as section "D" comprised of items that were 
used to assess utilization of EC. The research questionnaire was self-administered, but in instances where students asked for assistance it was readily provided by the data collection assistants. Data was entered into Microsoft excel 2013 version, cleaned and transported to the statistical package for social sciences (SPSS) version 22 for analysis. The data were analysed in to descriptive statistics and chi square test of relationship (c2).

\section{Ethical approval}

The study was reviewed by the scientific review committee of the School of Nursing and Midwifery in the University of Health and Allied Sciences and ethical clearance was obtained from the institute of health research [UHAS - REC A.2 (121) 18-19] of the
University of Health and Allied Health Science following recommendation by the latter. Also, permission was obtained from the Director/ Manager of each school. The purpose and significance of the research were explained to the study participants.

\section{RESULTS}

The sample size for this study was 260 students drawn from second cycle institutions in the Ho municipality. The mean age of the study participants was 17 with a minimum of 14 and a maximum of $25.92 .1 \%$ were Christians and $7.9 \%$ were Muslims. With respect to residence, $74.2 \%$ students reported as boarders and $24.2 \%$ as day students. Respondents indicated they were in first year $(25.8 \%)$ second year $(48.4 \%)$ and third year $(25.8 \%)$.

Table 1: Socio-demographic characteristics of senior high school female students.

\begin{tabular}{|c|c|c|c|}
\hline Characteristics & Variable & Frequency & Percentage \\
\hline \multirow{3}{*}{ Age in years } & Below 15 & $32-5$ & $1.1 \%$ \\
\hline & $15-20$ & 236 & $93.7 \%$ \\
\hline & $21-25$ & 13 & $5.2 \%$ \\
\hline \multirow{2}{*}{ Location of residence } & Ho municipality & 143 & $56.7 \%$ \\
\hline & Outside Ho municipality & 109 & $43.2 \%$ \\
\hline \multirow{2}{*}{ Religion } & Christian & 232 & $92.1 \%$ \\
\hline & Muslim & 20 & $7.9 \%$ \\
\hline \multirow{3}{*}{ Level in school } & One & 65 & $25.8 \%$ \\
\hline & Two & 122 & $48.4 \%$ \\
\hline & Three & 65 & $25.8 \%$ \\
\hline \multirow{3}{*}{ Presence of sexual partner } & Never married & 184 & $73.0 \%$ \\
\hline & In a relationship & 64 & $25.4 \%$ \\
\hline & Ignored & 4 & $1.6 \%$ \\
\hline \multirow{3}{*}{ Residential Status in school } & Residence & 187 & $74.2 \%$ \\
\hline & Non-residence & 61 & $24.2 \%$ \\
\hline & Ignored & 4 & $1.6 \%$ \\
\hline \multirow{3}{*}{ Source of pocket money } & Parent & 232 & $92.0 \%$ \\
\hline & Boyfriend & 6 & $2.4 \%$ \\
\hline & Engage in other works & 14 & $5.6 \%$ \\
\hline
\end{tabular}

The results from Table 2 showed that $(98.8 \%)$ of senior high school students have heard of emergency contraception. The knowledge about emergency contraception was gotten from friends $(36.9 \%)$, family members $(5.6 \%)$ and from the mass media (41.6\%). The study findings showed that $57.9 \%$ of Senior high students in the Ho municipality indicated that emergency contraception could be taken immediately after sex, 24 hours after sex $(1.2 \%)$ and $(30.6 \%)$ did not know the time period allowed for emergency contraceptives to be taken after sexual intercourse. Also, $57.1 \%$ of senior high students also showed that EC prevents unwanted pregnancies, whiles $(5.6 \%)$ of them indicated that it induces abortion and $(24.6 \%)$ said it prevents pregnancy as well induce abortion. Senior high students showed that the emergency contraceptive can be obtained from a pharmacy $(42.5 \%)$, hospital $(25.3 \%)$, private clinic $(16.7 \%)$. The perception of the effectiveness of EC pills for prevention of pregnancies, were that, its effective $(51.1 \%)$, highly effective $(25.3 \%)$, not effective $(3.6 \%)$, while $(17.1 \%)$ did not know the level of effectiveness.

Describing the situation when EC should be used, respondents indicated when forced to have sex (27.4\%), when a condom breaks or slip during sex $(31.0 \%)$, when there is a miscalculation of the safe period during the menstrual cycle $(25.8 \%)$ and when the woman fails to take the regular contraceptive pill (15.8\%). Respondents 
also believe the EC is very safe $(44.8 \%)$, safe $(36.5 \%)$, and unsafe $(10.3 \%)$.

Regarding indication of willingness to use EC in Table 3, $46.8 \%$ were in the affirmative while $52.8 \%$ will not. Noteworthy, $71.4 \%$ of the students indicated that provision of EC to students will encourage promiscuity. Respondents (28.4\%), indicated that they would not use
EC in the future because their religion was against its usage, (18.0\%) thought the drug is not effective and $(24.9 \%)$ believed it would be dangerous to their health.

The respondents said EC induced abortion (17.5\%) while $33.3 \%$ suggested EC should be available over the counter without prescription. Senior high students indicated that repeated use of EC poses a health risk (50.4\%).

Table 2: Knowledge of senior high students on the use of EC.

\begin{tabular}{|c|c|c|c|}
\hline Characteristics & Variable & Frequency & Percentage \\
\hline \multirow{3}{*}{$\begin{array}{l}\text { Ever discussed reproductive } \\
\text { health issues }\end{array}$} & Yes & 246 & $97.6 \%$ \\
\hline & No & 4 & $1.6 \%$ \\
\hline & Unanswered & 2 & $0.8 \%$ \\
\hline \multirow{5}{*}{$\begin{array}{l}\text { Person discussed the } \\
\text { reproductive issue with }\end{array}$} & Parent & 57 & $22.6 \%$ \\
\hline & Friend & 158 & $62.7 \%$ \\
\hline & Boyfriend & 4 & $1.6 \%$ \\
\hline & Another family member & 23 & $9.1 \%$ \\
\hline & Unanswered & 10 & $4.0 \%$ \\
\hline \multirow{2}{*}{$\begin{array}{l}\text { The issue regarding } \\
\text { reproductive health discussed }\end{array}$} & About EC & 154 & $61.1 \%$ \\
\hline & Not about EC & 98 & $38.9 \%$ \\
\hline \multirow{2}{*}{ Awareness of EC } & Yes & 249 & $98.8 \%$ \\
\hline & No & 3 & $1.2 \%$ \\
\hline \multirow{11}{*}{$\begin{array}{l}\text { First source of information on } \\
\text { EC }\end{array}$} & TV & 51 & $20.2 \%$ \\
\hline & Radio & 21 & $8.3 \%$ \\
\hline & Newspaper & 3 & $1.2 \%$ \\
\hline & Internet webpage & 30 & $11.9 \%$ \\
\hline & Parent & 10 & $4.0 \%$ \\
\hline & Friends & 93 & $36.9 \%$ \\
\hline & Reproductive health club & 7 & $2.7 \%$ \\
\hline & Health care providers & 14 & $5.6 \%$ \\
\hline & Boyfriend & 6 & $2.4 \%$ \\
\hline & Other family members & 14 & $5.6 \%$ \\
\hline & Ignored & 3 & $1.2 \%$ \\
\hline \multirow{10}{*}{$\begin{array}{l}\text { Common emergency } \\
\text { contraceptive methods used }\end{array}$} & Combined oral pills & 86 & $15.8 \%$ \\
\hline & Postinor 2 & 131 & $24.1 \%$ \\
\hline & Sugar solution & 26 & $4.7 \%$ \\
\hline & Cytotec & 10 & $1.8 \%$ \\
\hline & Lemon & 23 & $4.2 \%$ \\
\hline & IUD & 76 & $14.0 \%$ \\
\hline & Quinine & 2 & $0.4 \%$ \\
\hline & Lydia pills & 141 & $26.0 \%$ \\
\hline & Do not know & 44 & $8.1 \%$ \\
\hline & Herbal medicine & 4 & $0.7 \%$ \\
\hline \multirow{5}{*}{$\begin{array}{l}\text { Time frame to take a first dose } \\
\text { of EC after sex }\end{array}$} & Immediately after sex & 146 & $57.9 \%$ \\
\hline & Within 12 hours & 10 & $4.0 \%$ \\
\hline & Within 24 hours & 3 & $1.2 \%$ \\
\hline & After a missed period & 16 & $6.3 \%$ \\
\hline & Do not know & 77 & $30.6 \%$ \\
\hline \multirow{4}{*}{ Effect of EC } & Prevent pregnancy from occurring only & 144 & $57.1 \%$ \\
\hline & Induced abortion only & 14 & $5.6 \%$ \\
\hline & Prevent both pregnancy and induce abortions & 62 & $24.6 \%$ \\
\hline & Do not know & 32 & $12.7 \%$ \\
\hline Places to acquire EC & Hospital & 64 & $25.3 \%$ \\
\hline
\end{tabular}




\begin{tabular}{|lllll|}
\hline Characteristics & Variable & Frequency & Percentage \\
\hline & Private clinic & 42 & $16.7 \%$ \\
\cline { 2 - 4 } & Pharmacy & 107 & $42.5 \%$ \\
\cline { 2 - 4 } & Do not know & 39 & $15.5 \%$ \\
\hline \multirow{3}{*}{$\begin{array}{l}\text { Effectiveness of EC pills in } \\
\text { preventing pregnancy }\end{array}$} & Highly effective & 71 & $28.2 \%$ \\
\cline { 2 - 4 } & Effective & 129 & $51.1 \%$ \\
\cline { 2 - 4 } & Not effective & 9 & $3.6 \%$ \\
\cline { 2 - 4 } Situations to use EC & Do not know & 43 & $17.1 \%$ \\
\hline \multirow{5}{*}{ Safeness of EC to a woman } & Forced to have sex & 154 & $27.4 \%$ \\
\cline { 2 - 4 } & Condom breaks/slips & 174 & $31.0 \%$ \\
\cline { 2 - 4 } & Miscalculation of calendar method & 145 & $25.8 \%$ \\
\cline { 2 - 4 } & Missed pills & 89 & $15.8 \%$ \\
\cline { 2 - 4 } & Very safe & 113 & $44.8 \%$ \\
\cline { 2 - 4 } & Safe & 92 & $36.5 \%$ \\
\cline { 2 - 4 } & Unsafe & 26 & $10.3 \%$ \\
\cline { 2 - 4 } & Do not know & 21 & $8.3 \%$ \\
\hline
\end{tabular}

Table 3: Perception of emerge female senior high school students towards NCY contraceptive.

\begin{tabular}{|c|c|c|c|}
\hline Characteristics & Variable & Frequency & Percentage \\
\hline \multirow{2}{*}{$\begin{array}{l}\text { Perception of provision of EC to students } \\
\text { likely promote promiscuity }\end{array}$} & Yes & 180 & $71.4 \%$ \\
\hline & No & 72 & $28.6 \%$ \\
\hline \multirow{3}{*}{ Willingness to use or recommend EC } & Yes & 118 & $46.8 \%$ \\
\hline & No & 133 & $52.8 \%$ \\
\hline & Ignored & 1 & $0.4 \%$ \\
\hline \multirow{6}{*}{ Reasons for not using EC } & Religious reasons & 96 & $28.4 \%$ \\
\hline & Not effective & 61 & $18.0 \%$ \\
\hline & Dangerous to health & 84 & $24.9 \%$ \\
\hline & Regular contraceptive methods use & 10 & $2.9 \%$ \\
\hline & Partner opposition & 28 & $8.3 \%$ \\
\hline & Induced abortion & 59 & $17.5 \%$ \\
\hline \multirow{3}{*}{$\begin{array}{l}\text { EC should be available over the counter, } \\
\text { without prescription }\end{array}$} & Yes & 84 & $33.3 \%$ \\
\hline & No & 163 & $64.7 \%$ \\
\hline & Ignored & 5 & $2.0 \%$ \\
\hline \multirow{3}{*}{ Repeated use of EC Poses a health risk. } & Yes & 127 & $50.4 \%$ \\
\hline & No & 53 & $21.0 \%$ \\
\hline & Do not know & 72 & $28.6 \%$ \\
\hline \multirow{3}{*}{ EC possess effects on foetus } & Yes & 111 & $44.0 \%$ \\
\hline & No & 69 & $27.4 \%$ \\
\hline & Do not know & 72 & $28.6 \%$ \\
\hline \multirow{2}{*}{ Men influence on EC use } & Yes & 157 & $62.3 \%$ \\
\hline & No & 95 & $37.7 \%$ \\
\hline
\end{tabular}

In Table 4 , senior high students $(57.1 \%)$ have a history of the use of emergency contraceptive pills. The various types used include Lydia pills $(38.5 \%)$, postinor-2 (32.6\%) and combined oral pills (8.7\%). Senior high students indicated the EC should be used within 24 hours of unprotected sexual intercourse $(33.7 \%)$, within 48 hours $(3.6 \%)$, and within 72 hours $(0.0 \%)$.

The reasons for use of the pills include condom slipped (35.7\%), could not take contraceptive pills (33.7\%), forced to have unprotected sex $(8.2 \%)$ and miscalculation of the safe period $(22.4 \%)$. The majority $(85.0 \%)$ of respondents agreed the EC methods are effective. The people who recommended the use of EC included friends $(64.4 \%)$, sexual partner $(23.1 \%)$ and health care provider $(6.7 \%)$. The sources of EC method included pharmacy $(92.9 \%)$ and health care facilities $(7.1 \%)$. Respondents have used EC in the last year, more than once $(21.8 \%)$, four times $(36.4 \%)$ and three times $(29.1 \%)$. The reasons for none use of EC include religious reasons $(62.9 \%)$, lack of adequate information on the method (13.1\%), consistent use of the calendar method $(9.1 \%)$ and high cost of EC $(2.3 \%)$. The relationship of the age distribution and the used of emergency contraception, as 
in Table 5 determined through a chi square analysis. The results showed that below 15 years $(66.6 \%), 15$ to 20 years $(65.7 \%)$ and all girls between 21 to 25 years reported to have ever used an emergency contraceptive $(\mathrm{p}=0.000, \mathrm{c} 2=8.128, \mathrm{n}=260)$.

Also, regarding the perception of safety of contraception against respondents ever used contraception, the results showed that, very safe $(90 \%)$, sage $(50 \%)$, unsafe $(3.8 \%)$ and do not know (23.8\%) were the people who reported to have ever used and emergency contraception $(\mathrm{p}=0.000$, $\mathrm{c} 2=8.28, \mathrm{n}=260$ ). In a cross tabulation of the use of presence of a sexual partner and the respondent indicating if they ever used and emergency contraception, the results showed that never married (43.8\%), in a current relationship (92.2\%) and all who ignored their relationship status reported to have ever used and emergency contraction $(\mathrm{p}=0.001, \mathrm{c} 2=13.385, \mathrm{n}=260)$.

Table 4: Utilization of EC among female senior high school students.

\begin{tabular}{|c|c|c|c|}
\hline Characteristics & Variable & Frequency & Percentage \\
\hline \multirow{3}{*}{ History of EC use } & Yes & 107 & $42.5 \%$ \\
\hline & No & 140 & $55.6 \%$ \\
\hline & Ignored & 5 & $1.9 \%$ \\
\hline \multirow{4}{*}{ EC method used } & Combined oral pills & 9 & $8.7 \%$ \\
\hline & Postinor-2 & 34 & $32.6 \%$ \\
\hline & Lydia pills & 40 & $38.5 \%$ \\
\hline & Condom & 21 & $20.2 \%$ \\
\hline \multirow{3}{*}{$\begin{array}{l}\text { Duration prior to use after } \\
\text { sexual intercourse. }\end{array}$} & Within 24 hours & 84 & $90.3 \%$ \\
\hline & Within 48 hours & 9 & $9.7 \%$ \\
\hline & Within 72 hours & 0 & $0.0 \%$ \\
\hline \multirow{4}{*}{$\begin{array}{l}\text { Reason for using } \mathrm{EC} \text { at that } \\
\text { time. }\end{array}$} & Miscalculation of safe period & 22 & $22.4 \%$ \\
\hline & Failed to use any contraception & 33 & $33.7 \%$ \\
\hline & Forced to have unprotected sex & 8 & $8.2 \%$ \\
\hline & Condom slipped/broken & 35 & $35.7 \%$ \\
\hline \multirow{2}{*}{ Method being effective } & Yes & 91 & $85.0 \%$ \\
\hline & No & 16 & $15.0 \%$ \\
\hline \multirow{4}{*}{$\begin{array}{l}\text { Source of recommendation for } \\
\text { EC use }\end{array}$} & Friend & 67 & $64.4 \%$ \\
\hline & Partner & 24 & $23.1 \%$ \\
\hline & Internet webpage & 6 & $5.8 \%$ \\
\hline & Health care provider & 7 & $6.7 \%$ \\
\hline \multirow{2}{*}{ Place service sort } & Hospital & 7 & $7.1 \%$ \\
\hline & Pharmacy & 91 & $92.9 \%$ \\
\hline \multirow{3}{*}{$\begin{array}{l}\text { Used EC more than one } \\
\text { occasion }\end{array}$} & Yes & 55 & $21.8 \%$ \\
\hline & No & 182 & $72.2 \%$ \\
\hline & Ignored & 15 & $6.0 \%$ \\
\hline \multirow{7}{*}{$\begin{array}{l}\text { Number of EC use within the } \\
\text { last year }\end{array}$} & $2 \mathrm{x}$ & 2 & $3.6 \%$ \\
\hline & $3 \mathrm{x}$ & 16 & $29.1 \%$ \\
\hline & $4 \mathrm{x}$ & 20 & $36.4 \%$ \\
\hline & $5 \mathrm{x}$ & 5 & $9.1 \%$ \\
\hline & $6 \mathrm{x}$ & 3 & $5.4 \%$ \\
\hline & $7 \mathrm{x}$ & 4 & $7.3 \%$ \\
\hline & $8 \mathrm{x}$ & 5 & $9.1 \%$ \\
\hline \multirow{6}{*}{ Reason for not using EC. } & Use regular contraceptive correct & 12 & $6.9 \%$ \\
\hline & Use safe period correctly & 16 & $9.1 \%$ \\
\hline & Inadequate information on $\mathrm{EC}$ & 23 & $13.1 \%$ \\
\hline & No access to EC & 10 & $5.7 \%$ \\
\hline & Cost of EC- not affordable & 4 & $2.3 \%$ \\
\hline & Religious/moral reasons & 110 & $62.9 \%$ \\
\hline \multirow{3}{*}{ Challenges faced in getting EC. } & Fear of stigma & 98 & $57.6 \%$ \\
\hline & Price involved & 29 & $17.1 \%$ \\
\hline & Lack of knowledge & 43 & $25.3 \%$ \\
\hline
\end{tabular}


In Table 6, there was a significant association between the level of respondents in school and the perception of the effects of EC use ( $p=0.001, c 2=3.3904, n=260)$. The response showed that majority of second year students $(55.6 \%)$ indicated the EC prevents pregnancy, while only $20.8 \%$ chose this option with $23.6 \%$ of the third-year students. Also, majority of first years (42.9\%) showed that EC only induce abortion. There was also a significant relationship of the level of education and the respondents' perception of the time to take and emergency contraceptive pill after having a sexual intercourse $(\mathrm{p}=0.002, \mathrm{c} 2=14.3435, \mathrm{n}=260)$. The results showed that first year students indicated that the pill can be taken immediately after sex $(31.5 \%)$, within 12 hours of sex (50.0\%, after a missed period $(12.0 \%)$ and do not know when to take the pill $(15.6 \%)$ while that of the third years showed that immediately after sex (15.8\%), within 24 hours after sex (100\%), after a missed period $(56.3 \%)$ and do not know when to take the contraception after sex $(39.0 \%)$.

Table 5: Relationship between ever used EC and some factors influencing the utilization of EC (n=260).

\begin{tabular}{|c|c|c|c|c|}
\hline \multirow{2}{*}{\multicolumn{2}{|c|}{ Factors }} & \multicolumn{2}{|l|}{ Use of EC } & \multirow{5}{*}{$\begin{array}{l}c 2 \text { and } p \text { value } \\
\mathrm{c} 2=8.128 \\
\mathrm{p}=0.000\end{array}$} \\
\hline & & Never used & Ever used EC & \\
\hline \multirow{3}{*}{$\begin{array}{l}\text { Age } \\
\text { distribution }\end{array}$} & Below 15 years & $1(33.4 \%)$ & $2(66.6 \%)$ & \\
\hline & 15 to 20 years & $81(34.3 \%)$ & $155(65.7 \%)$ & \\
\hline & 21 to 25 years & $0(0 \%)$ & $13(5.2 \%)$ & \\
\hline \multirow{4}{*}{$\begin{array}{l}\text { Perception of } \\
\text { safety of EC }\end{array}$} & Very safe & $14(10 \%)$ & $99(90 \%)$ & \multirow{4}{*}{$\begin{array}{l}\mathrm{c} 2=8.28 \\
\mathrm{p}=0.000\end{array}$} \\
\hline & Safe & $46(50 \%)$ & $46(50 \%)$ & \\
\hline & Unsafe & $25(96.2 \%)$ & $1(3.8 \%)$ & \\
\hline & Do not know & $16(76.2 \%)$ & $5(23.8 \%)$ & \\
\hline \multirow{3}{*}{$\begin{array}{l}\text { Presence of } \\
\text { sexual partner }\end{array}$} & Never married & $105(57 \%)$ & $79(43 \%)$ & \multirow{3}{*}{$\begin{array}{l}c 2=13.385 \\
p=0.001\end{array}$} \\
\hline & In a relationship & $5(7.8 \%)$ & $59(92.2 \%)$ & \\
\hline & Ignored & $0(0 \%)$ & $4(100 \%)$ & \\
\hline
\end{tabular}

Table 6: Relationship of the level of education and the perception of the use of emergency contraception $(n=260)$.

\begin{tabular}{|c|c|c|c|c|c|c|}
\hline Variables & Parity & One (65) & Two (122) & Three (65) & Total & c2, p-value \\
\hline \multirow{4}{*}{$\begin{array}{l}\text { Association between } \\
\text { level in school and } \\
\text { perception of the } \\
\text { effects of EC use }\end{array}$} & $\begin{array}{l}\text { Prevent pregnancy from } \\
\text { occurring only }\end{array}$ & $30(20.8 \%)$ & $80(55.6 \%)$ & $34(23.6 \%)$ & 144 & \multirow{4}{*}{$\begin{array}{l}c 2=3.3904 \\
p=0.001\end{array}$} \\
\hline & Induced abortion only & $6(42.9 \%)$ & $4(28.6 \%)$ & $4(28.6 \%)$ & 14 & \\
\hline & $\begin{array}{l}\text { Prevent both pregnancy } \\
\text { and induce abortions }\end{array}$ & $19(30.6 \%)$ & $32(51.6 \%)$ & $11(17.7 \%)$ & 62 & \\
\hline & Do not know & $10(31.2 \%)$ & $6(18.8 \%)$ & $16(50.0 \%)$ & 32 & \\
\hline \multirow{5}{*}{$\begin{array}{l}\text { Association of level of } \\
\text { education and time to } \\
\text { take the first doze of } \\
\text { emergency } \\
\text { contraception after sex }\end{array}$} & Immediately after sex & $46(31.5 \%)$ & $77(52.7 \%)$ & $23(15.8 \%)$ & 146 & \multirow{5}{*}{$\begin{array}{l}\mathrm{c} 2=14.3435 \\
\mathrm{p}=0.002\end{array}$} \\
\hline & Within 12 hours & $5(50.0 \%)$ & $0(0.0 \%)$ & $0(0.0 \%)$ & 10 & \\
\hline & Within 24 hours & $0(0.0 \%)$ & $0(0.0 \%)$ & $3(100.0 \%)$ & 3 & \\
\hline & After a missed period & $2(12.5 \%)$ & $5(31.3 \%)$ & $9(56.3 \%)$ & 16 & \\
\hline & Do not know & $12(15.6 \%)$ & $35(45.5 \%)$ & $30(39.0 \%)$ & 77 & \\
\hline
\end{tabular}

\section{DISCUSSION}

This study assessed the knowledge and utilization of emergency contraction among senior high students in the Ho municipality. The level of awareness among respondents regarding emergency contraception was $98.8 \%$. The high level of awareness of the existence of emergency contraception is a good requisite for respondents to take action towards preventing pregnancy if there is a need. The level of awareness of emergency contraception has always been high in Ghana following heightened public education especially within this cadre. In Cape Coast $81 \%$ senior high school students indicated they had knowledge about emergency contraception. ${ }^{12}$
Emergency contraception may be necessary when an individual does not take the appropriate steps prior to intercourse to prevent pregnancy. Emergency contraception may be required when contraception is not available at the time intercourse occurs, or if the couple was not planning beforehand to have intercourse. EC can delay or prevent ovulation, impair formation of the corpus luteum or cause histological or biochemical changes within the endometrium thus preventing implantation. ${ }^{13}$ In this study, the level of awareness is however high compared to what was reported in a study conducted in Ethiopia by Tamire and Enqueselassie. ${ }^{14}$ In Seto Semero high school, Jimma Town, South West Ethiopia, where $40.5 \%$ of respondents reported that they 
had ever heard about emergency contraception methods. Poor user awareness and access, have hindered adolescents in learning and using Emergency contraception. ${ }^{14}$ Despite high rates of unprotected intercourse, only $8 \%$ of teenagers have used the emergency contraceptive pill in the USA in recent years. ${ }^{1}$ Adolescent girls in Ghana had various sources where this information about emergency contraception pill was obtained. The sources of this information include friends $(36.9 \%)$, television $(20.2 \%)$, internet webpage (11.9\%), radio $(8.3 \%)$, reproductive health clubs $(2.8 \%)$ and health care providers $(5.6 \%)$. The most extensive source of knowledge is an asset to reproductive health care agencies to use diverse means of conveying information to target groups. In the Cape Coast metropolis Hagan reported knowledge about contraception was obtained from the media $(60 \%)$ and peers $(30 \%){ }^{12}$ In Ethiopia among the same cadre of respondents, results showed that source of knowledge about EC was from television and radio $(43.0 \%)$, hospital $(21.0 \%)$, friends $(18.0 \%)$, family $(14.0 \%)$ and spouse (4.0\%) 4 Obi and Ozumba, 2008 reported that the lack of dependable information on EC was glaring as most respondents erroneously thought that some post coital traditional practices were effective modern EC. Even among those with knowledge about $\mathrm{EC}$, there was some confusion about the recommended maximum length of time following intercourse that a woman could begin the regime. ${ }^{16}$ For most of them, the term 'morning after pill' implies that a woman must wait until the next morning (i.e. 12-24 hours) after intercourse to begin use. Only a few (3.4\%) respondents knew of post coital intrauterine contraceptive device (IUCD) use. ${ }^{13}$

The results showed that $42.5 \%$ of senior high students in the Ho metropolis have had a history of EC use. The use of EC comes with inherent challenges and the use of alternative modern contraceptive methods to replace EC cannot be overemphasized. Nonetheless, there is a need to offer contraceptive services to young women who are intermittently sexually active in less stable types of relationships. ${ }^{15}$ As sexual activities among senior high students have been reported by the Ghana demographic and health survey, increasing knowledge and access to the use of this important service is necessary in reducing the high rate of maternal mortality that is associated with abortions, especially in this cadre of the population. Senior high students $(46.8 \%)$ that had an awareness of EC were willing to use EC or recommend it to others when the need arises. This reinvigorates the fact that the use of the method is generally pervasive among African adolescents. In Ghana, emergency contraception is sold as an over the counter medications and sometimes by even unauthorized chemical sellers. The use as well as recommending others to use the emergency contraception is therefore a common practice among sexually active persons, for example, it was reported that $72.2 \%$ of engineering college girls either agreed or strongly agreed that they would use EC in the future if the need arises 16. Reasons some respondents will not use or recommend the use of the emergency contraction include religious reasons (28.4\%), perceived as injurious to health $(24.9 \%)$, method not effective $(18.0 \%)$ and the belief that the method is an abortifacient (17.5\%).

The use of emergency contraception has always been bedeviled with public perception of promiscuity. In this study, $72.4 \%$ of senior high school students indicated knowledge and use of emergency contraception is likely to encourage sexual promiscuity. The use of emergency contraception seeks to prevent pregnancy when the woman does not wish to be. Sexual intercourse does not usually in most instances occur without the consent of the women involved and the use of emergency contraception will help curtail the resultant repercussions of such sexual encounters. In a study of 400 primary school students, $49 \%$ of sexually active girls were reported to have had forced sex. ${ }^{17}$ The high sexual violence, lack of access to and low utilization of family planning services in developing countries contribute to the high rate of unintended pregnancies. ${ }^{18}$ The use of emergency contraception will remain useful this person who has had to receive non consenting and coerced sexual encounters. The use of emergency contraception, especially the hormonal method should only be done in an emergency situation. When a woman stands the risk of using this method repeatedly within a short period of time, the use of alternative contraceptive methods should be encouraged. Adolescent girls (50.4\%) indicated that the continuous use of the emergency contraceptive poses a risk to their reproductive life. ${ }^{2}$ Inherent in the use of the EC are major side effects. With respect to the increasing adolescent sexual activity and decreasing age at first sex in developing countries, the use of contraceptives to prevent unwanted pregnancy, unsafe abortion and minimize the risk of STIs transmission is especially important. ${ }^{19}$ Some senior high students (44.0\%) belief that the fetus is at risk if one should use EC and it fails. With some misconceptions associated with this method of contraception, increasing public education, especially among adolescent is essential. Kebede, 2006 reported that among those who are aware of emergency contraception, its usage rate is very low since the information they have regarding the methods and the timing of emergency contraception was not sufficient. ${ }^{5}$

Adolescent girls showed high knowledge of the various contraceptive methods. The methods commonly used include emergency contraceptive pills (Lydia pills) $(38.5 \%)$, postinor-2 $(32.6 \%)$ and combined oral pills $(8.7 \%)$. The knowledge on variety of EC available gives respondents an option to choose from. Also, $36.1 \%$ respondents believed easy accessibility of EC at the pharmacy and easiness of use of emergency contraceptive pills are the reason for its patronage. In contrast, IUDs needs trained health care professionals to be administered and this is only provided at healthcare institutions. A cross-sectional study done on 561 female students of Mekelle University of Northern Ethiopia, showed that $44.7 \%$ of the total respondents had ever heard of emergency contraception. $88.04 \%$ of them had ever heard 
of EC mentioned pills, 3.18\% intrauterine device (IUD) and the remainder $8.76 \%$ mentioned injection and implant. ${ }^{14}$ The level of perception of the effectiveness of the contraception methods was shown to be $85 \%$. The use of modern emergency contraception was found to be common as respondents used it up to thrice $(29.1 \%)$ and four times $(36.4 \%)$. Female students in Mizan-Tepi University, South West Ethiopia showed that only $36.2 \%$ had ever used EC. ${ }^{20}$ Having adequate information on the appropriate use of the emergency contraceptive pill is central to the efficacy and mitigating undesirable effects following inappropriate use. People, and especially adolescents must be given this essential information to improve on the gains made through family planning.

On the role of a relationship to the use of emergency contraception, the results showed that married (43.8\%), in a current relationship (92.2\%) and all who ignored their relationship status reported to have ever used and emergency contraction ( $\mathrm{p}=0.001, \mathrm{c} 2=13.385, \mathrm{n}=260)$. The majority of senior high students in a current relationship are actively using the emergency contraction. This continues use even though may prevent them from having pregnancy can have a dire consequence on their overall reproductive health. Opposition to the use of emergency contraception by unmarried women has been because of the belief that it has some adverse health effect $(12.1 \%)$, induces abortion $13.4 \%$ in the future and for religious reasons $(7 \%$ ) while $67 \%$ favored the use of EC by unmarried women. ${ }^{13}$ Opposition to the use of EC by unmarried women is because of the belief that it has some health effect $(n=72)$, induces abortion $(n=80)$ and for religious reasons $(n=42)$. Obi and Ozumba, 2008 concluded that the unmarried women's knowledge of EC, its availability and use is limited due to insufficient information, poor education, inaccessibility and service provider's attitude. ${ }^{13}$ There was also a significant relationship of the level of education and the respondents' perception of the time to take and emergency contraceptive pill after having a sexual intercourse $(p=0.002, c 2=14.3435, n=260)$. The role of education in the use of EC has been documented by Fernandes, D'souza, and Karkada, indicated that there was a significant association $(\mathrm{p}=0.002)$ between education and knowledge regarding emergency contraception. ${ }^{21}$ Only one selected variable like education showed (likelihood ratio, $\mathrm{c} 2=12.934, \mathrm{p}=0.002){ }^{21}$ There was a significant association between the level of respondents in school and the perception of the effects of EC use $(p=0.001$, $c 2=3.3904, n=260)$. This depicts that the higher one got in school or older the likelihood of use of EC increase. Yidana, Ziblim, Azongo, and Abass, 2015 found that older female adolescents were more than three times likely to practice contraceptive use than younger female adolescents. Perhaps, this is because older female adolescents are more mature and enlightened in terms of available contraceptive types and the importance of contraceptive use, compared to younger female adolescents who may be comparatively naive in terms of contraception. ${ }^{22}$
Marital status also had significant relationship with contraceptive use among female adolescents. Consequently, contraceptive use was more likely among adolescents who were married or living together than among those who were not married $(\mathrm{p}=0.001, \mathrm{c} 2=13.385$, $\mathrm{n}=260$ ). This confirms findings of a study conducted by Clemens and Madise which found a significant relationship between marital status and contraceptive use in Ghana. ${ }^{23}$ On the contrary, studies including NketiahAmponsah, Arthur, Abuosi, and Okech, Wawire, Mburu, found no significant relationship between marital status and use of contraceptives among females. ${ }^{24,25}$

\section{CONCLUSION}

There is the need to avail accurate information to female senior high school students on emergency contraceptive methods. Strengthening education in senior high schools on sexual and reproductive health, with special emphasis on emergency contraceptives as a pregnancy preventive procedure will remain imperative to reducing the menace of maternal mortality attributed to adolescent abortions. The role of parents in adolescent reproductive health is central in supporting girls to make informed decisions about their reproductive health including the emergency contraceptive use. Also, specific policies should guide clinical nurse/midwife on issues such as non-judgmental attitude towards sexually active female senior high students and facilitating students' access to emergency contraceptive services while making available other sexual reproductive health options. Education on awareness of EC products through mass media, particularly laying more emphasis on the frequency of use and time limit to take emergency contraceptive after unprotected sexual intercourse would be more crucial in reducing the risk associated with unwarranted and overuse of these services.

\section{Funding: No funding sources Conflict of interest: None declared \\ Ethical approval: The study was approved by the Institute of Health Research [UHAS - REC A.2 (121) 18-19] of the University of Health and Allied Health Science}

\section{REFERENCES}

1. World Health Organization. Guideline: Iron supplementation in postpartum women, 2016. Available at: https://apps.who.int/iris/bitstream/ handle/10665/249242/9789241549585-eng.pdf.

Accessed on $4^{\text {th }}$ May 2018.

2. World Health Organization. International statistical classification of diseases and related health problems. World Health Organization; 2004:1.

3. World Health Organization. International statistical classification of diseases and related health problems: $10^{\text {th }}$ revision (ICD-10), 1992. Available at: http://www.who.int/classifications/apps/icd/icd. Accessed on $28^{\text {th }}$ April 2018. 
4. Okeke PU. Anaemia in pregnancy-is it a persisting public health problem in Porto Novo-Cape Verde?. Res J Med Sci. 2011;5(4):193-9.

5. Ezugwu EC, Mbah BO, Chigbu CO, Onah HE. Anaemia in pregnancy: a public health problem in Enugu, South-east Nigeria. J Obstet Gynaecol. 2013;33(5):451-4.

6. Pasricha SR, Drakesmith H, Black J, Hipgrave D, Biggs BA. Control of iron deficiency anemia in lowand middle-income countries. Blood. The J Am Society Hematol. 2013;121(14):2607-17.

7. McLean E, Cogswell M, Egli I, Wojdyla D, De Benoist B. Worldwide prevalence of anaemia, WHO vitamin and mineral nutrition information system, 1993-2005. Pub Health Nutrit. 2009;12(4):444-54.

8. Msuya SE, Hussein TH, Uriyo J, Sam NE, StrayPedersen B. Anaemia among pregnant women in northern Tanzania: prevalence, risk factors and effect on perinatal outcomes. Tanzania $\mathrm{J}$ Health Res. 2011;13(1):33-9.

9. Mbule AM, Byaruhanga YB, Kabahenda M, Lubowa A. Determinants of anaemia among pregnant women in rural Uganda. Rural Remote Health. 2013;13(2):2259.

10. M'cormack FA, Drolet JC. Assessment of anemia knowledge, attitudes and behaviors among pregnant women in Sierra Leone. Health Educator. 2012;44(2):9.

11. Kotey A. The Causes of Anaemia in Agogo, Ashanti Region, Ghana (Doctoral dissertation). 2012. Available at: http://dspace.knust.edu.gh/handle/ 123456789/5437. Accessed on $20^{\text {th }}$ March 2020.

12. Salhan S, Tripathi V, Singh R, Gaikwad HS. Evaluation of hematological parameters in partial exchange and packed cell transfusion in treatment of severe anemia in pregnancy. Anemia. 2012:2012.

13. Demographic G. Health Survey (GDHS) Ghana statistical service Accra, Ghana health service (GHS). Accra, Ghana The DHS Program ICF International Rockville, Maryland, USA; 2014.

14. Ghimire N, Pandey N. Knowledge and practice of mothers regarding the prevention of anemia during pregnancy, in teaching hospital, Kathmandu. J Chitwan Med College. 2013;3(3):14-7.

15. Dougul Regis M, Padmavathi R. A prospective clinico hematological study in 100 cases of pancytopenia in a tertiary care teaching hospital. Int J Res Med Sci. 2019;7(7):2610.

16. Konlan KD, Kombat JM, Bapuah MA, Wuffele GM. The use of sulphadoxinepyrimethamine as a malaria prophylaxis for pregnant women in the Volta Regional Hospital. Int $\mathbf{J}$ Med Health Sci. 2018;7(4):182-8.
17. Nisar YB, Alam A, Aurangzeb B, Dibley MJ. Perceptions of antenatal iron-folic acid supplements in urban and rural Pakistan: a qualitative study. BMC Preg Childbirth. 2014;14(1):344.

18. Konlan KD, Kombat JM, Japiong M, Konlan KD. Perception of pregnant women on maternity care services at the Volta Regional Hospital, Ghana. Int J Comm Med Public Health. 2018;5(7):2699.

19. Pettifor A, Taylor E, Nku D, Duvall S, Tabala M, Meshnick S, Behets F. Bed net ownership, use and perceptions among women seeking antenatal care in Kinshasa, Democratic Republic of the Congo (DRC): opportunities for improved maternal and child health. BMC Public Health. 2008;8(1):331.

20. Chacko R, Premkumar U, Joseph M, James J, Prabha S, Jacob MK, et al. Knowledge, Attitude and practices of anemia among pregnant women in a Government hospital. Indo Am J Pharmal Res. 2016;6(11):6988-92.

21. Chang S, Zeng L, Brouwer ID, Kok FJ, Yan H. Effect of iron deficiency anemia in pregnancy on child mental development in rural China. Pediatr. 2013;131(3):e755-63.

22. deBritoJúnior LC, Estácio AG. Food taboos in medicine: a hypothesis for pathophysiology regarding harmful food. Revista da Associação Médica Brasileira (English Edition). 2013;59(3):2136.

23. Arzoaquoi SK, Essuman EE, Gbagbo FY, Tenkorang EY, Soyiri I, Laar AK. Motivations for food prohibitions during pregnancy and their enforcement mechanisms in a rural Ghanaian district. J Ethnobiol Ethnomed. 2015;11(1):59.

24. Patience DI. Knowledge and perception of risk of anaemia during pregnancy among pregnant women in Ablekuma South (Doctoral dissertation, University of Ghana). 2016. Available at: http://ugspace.ug.edu.gh/handle/123456789/21512. Accessed on $10^{\text {th }}$ March 2020.

25. Okoh DA, Iyalla C, Omunakwe H, Iwo-Amah RS, Nwabuko C. A retrospective study of the prevalence of anaemia in pregnancy at booking in Niger Delta, Nigeria. J Obstet Gynaecol. 2016;36(5):594-7.

Cite this article as: Konlan KD, Amoah RM, Saah JA, Doat AR, Konlan KD, Japiong M, et al. The use of emergency contraception among female senior high students in the Ho municipality of the Volta Region, Ghana. Int J Reprod Contracept Obstet Gynecol 2020;9:2383-92. 